Marco PETRELLI

Department of Modern Languages, Literatures, and Cultures, University of Bologna

Bologna, Italy

marco.petrelli2@unibo.it

\title{
POST-SOUTHERN GEOGRAPHIES: SPACE AND LITERATURE IN THE CONTEMPORARY AMERICAN SOUTH
}

Recommended Citation: Petrelli, Marco. "Post-Southern Geographies: Space and Literature in the Contemporary American South". Metacritic Journal for $\begin{array}{lllll}\text { Comparative } & \text { Studies } & \text { (2020): }\end{array}$ https://doi.org/10.24193/mjcst.2020.9.03

\begin{abstract}
From a geocritical standpoint, American gothic literature historically relies on the symbolical space of the wilderness: a labyrinthine parapsychological realm of darkness and irrationality, and a rhetorical inversion of pastoral motives. The traditional sense of place of the American South stems from society's projected cultural values on the environment and from a strict separation of Garden and Wasteland. This separation was no longer held after agricultural capitalism swept the region in the 1920 s and 1930s, changing the landscape forever and bringing about semiotic chaos in what was once an orderly landscape of Jeffersonian descent. With the advent of the post-southern era, as described by Martyn Bone, literature struggled to redefine pastoral and gothic chronotopes in a quest for new geographical grounds in which the fragmented collective identity of the region could be rooted. Through the analysis of contemporary southern works, this essay aims at re-defining pastoral and gothic spaces in post-southern America.
\end{abstract}

Keywords: Southern US Southern Gothic, Pastoralism, Post-South, Sense of Place.

During the American Civil War, Confederate troops appropriated the popular minstrel song Dixie (originally a satirical tune) and turned it into a battle hymn, adding the notoriously defiant lines "In Dixie Land I'll take my stand / To live and die in Dixie". The song was a favourite among troops on the march, in camp, and at battle (Cornelius 37). The cultural relevance of the tune in relation to Southern United States is 
demonstrated by the fact that it provided the title for the most important work of conservative cultural thought ever produced by southern letters, the Twelve Southerners' I'll Take My Stand. Assembled as an intellectual backlash against the increasing industrialization of the region and the progressive dislocation of small farmers at the hands of agricultural capitalism, this collection of essays marks a turning point in the way white southern space and identity were to be read and depicted by the next generation of writers.

In his insightful essay on the literature and culture of the South, Inventing Southern Literature, Michael Kreyling goes as far as to declare that I'll Take My Stand "serves as a script for inventing southern identity" (171). Stressing the fact that the Twelve Southerners published their manifesto in conjunction with a historical moment in which the traditional way of looking at the South was in crisis due to modernization (and the still-palpable psychological aftermath of the Civil War), Kreyling also declares southern identity to be inherently linked to "anxiety and estrangement" (172). In the clash between modernity and tradition, and between rural and industrial societies, the conservative southern mind was caught in a conundrum: how to preserve its attachment to "a certain terrain, a certain history, and a certain inherited way of living" (Ransom 1). The fact that Ransom places land in first place on his list of the fundamental cultural references for a southerner is revealing of the pivotal role that space plays in the literature of the South and in southern identity at large. To build (or rebuild) the South through literature, Allen Tate and his colleagues needed to provide some ground first.

As highlighted also by Martyn Bone in The Postsouthern Sense of Place in Contemporary Fiction, the Twelve Southerners' operation of cultural re-construction is also the invention of a place (vii): an agrarian landscape that was more of a myth than a reality, even in 1930. Of course, the South of the first decades of the twentieth century was not the thriving industrial Moloch that the group of writers denounces. However, the traditional rural world was evolving fast enough for the Twelve Southerners to react with vehemence against their contemporary times. The South they had in mind hardly coincided with the threatened (but still lingering) socioeconomic system of agricultural real property. It was instead consciously shaped upon antebellum cultural geographies filtered through the unavoidable mythical realm of the pastoral - from a southern, conservative point-of-view. I'll Take My Stand builds on a clear anti-capitalist but decidedly not Marxist stance, as the introduction 
of the volume clearly states. From a historical-materialistic point of view, the roots of its ideology are to be found in the far more nebulous world of literary myths that have been superimposed on the North American landscape. When the Twelve Southerners write that the agrarian society they refer to "does not stand in particular need of definition" (l), they are both playing with and seducing the traditional mind of the white South's instinctive, archetypal attachment to a conception of land that dates back to the founding ideals of the United States.

It is not a coincidence that I'll Take My Stand's celebration of agricultural property closely resembles Thomas Jefferson's republicanism. Shaping his thought on agrarianism and the quasi-heroic figure of the yeoman, Jefferson, a southerner and a planter, gave the South (and a significant portion of southern literature) its mythical and political foundations. His Notes on the State of Virginia, arguably the first consciously southern work of literature in the history of the US, creates the single most important mytheme (a fundamental set of narrative units from which a myth is constructed) in white southern letters' tradition: the pastoral connection between man and landscape. In this context, the term pastoral is to be understood both in its religious and literary meanings. The religious dimension of the southern pastoral, mostly in the background of Jefferson's rural democracy as defined in Notes on the State of Virginia (and especially in query XIX) symbolically derives, as Lewis P. Simpson argues in The Dispossessed Garden: Pastoral and History in Southern Literature, from Puritan spiritual geographies. Obsessed by the will to recreate a New Eden in the New World as the true chosen people of God, the Puritan settlers envisioned their mission as an "errand into a howling wilderness, in the midst of which as God's regenerate band they would make a pleasure garden for Him" (Simpson, Dispossessed 15). Through the protection obtained from the covenant with God, the Pilgrims braved "the devil's territories" in order to turn them into a pastoral haven.

As Puritan chronicles and later literary works inspired by the Puritan milieu demonstrate, the distinction between garden and wilderness was also a kind of parapsychological division between the safe and ordered holy space of the community and the devilish, chaotic, and unknown territories outside of it (as in the classic example of Nathaniel Hawthorne's "Young Goodman Brown"). In Landscapes of Fear, geographer Yi-Fu Tuan traces a common tendency among pioneer societies to identify

\footnotetext{
${ }^{1}$ This famous definition is taken from Cotton Mather's Wonders of the Invisible World (xi)
} 
the space outside of villages as increasingly threatening in relation to how much people advanced deep into the surrounding wilderness. He writes that "under such circumstances, the imagination is quick to populate space with lurking evil spirits," (Tuan 55). If one accepts Simpson's simple and functional definition of the gothic as "an inversion of the motives of the Western pastoral mode" (Introduction $\mathrm{x}$ ), and then projects it upon the landscape, it is possible to define the literary Puritan wilderness as a quintessential gothic space. As Weston describes it, the gothic space is "the most basic element" (Weston 18) of gothic fiction. It is "a psychological or parapsychological realm that impinges upon the everyday world of actuality (...) a complex and unpredictable setting that surrounds a center of suspense (...) that heightens the exposed nature of the human being who is trapped there" (Weston 19).

The clear distinction between the inside and the outside that the Puritan mind applied to the new continent gained a slightly different shape in the South. Southern geographies, probably gentler in appearance to the first settlers with respect to the more threatening northern shores, inspired comparison with an earthly paradise. "The influence of the Southern physical world," writes W.J. Cash in his The Mind of the South, was "itself a sort of cosmic conspiracy against reality in favour of romance. The country is one of extravagant colours, of proliferating foliage and bloom, of flooding yellow sunlight, and, above all, perhaps, of haze" (46). In a similar way, Lewis P. Simpson discriminates between the New England pastoral and the southern pastoral by writing that the pilgrims perceived their mission in these lands as "an errand into an open, prelapsarian, self-yielding paradise, where they would be made regenerate by entering into a redemptive relationship with a new and abounding earth" (Dispossessed 15). The regenerative power of the land was later to be re-elaborated by Jefferson in his praise of the yeomen and the "substantial and genuine virtue" (176) that they gathered from the earth. This is exactly the kind of utopian rural society that the Twelve Southerners promoted in I'll Take My Stand in an effort to fight back against the modernization of the South.

If the gothic literary space is to be understood as an inversion of the pastoral space as Simpson writes, then where does the Gothicism of the South come from in terms of the relation between a society and the space it occupies? An interesting answer comes again from Simpson, who highlights a fundamental fallacy in Jefferson's socio-geographic political theory as presented in Notes on the State of Virginia. In query XVII, the future president of the United States dedicates some alarmed words 
to the stability of the society he envisioned, finding in slavery a threat to the spontaneous virtuosity of a democracy based on land. "There must doubtless be an unhappy influence on the manner of our people produced by the existence of slavery among us" (Jefferson 173), he writes (not without hypocrisy, since Jefferson himself was a slave owner). His vision borders on the apocalyptic:

in a warm climate, no man will labour for himself who can make another labour for him. This is so true, that of the proprietors of slaves a very small proportion indeed are even seen to labour. And can the liberties of a nation be thought secure when we have removed their only firm basis, a conviction in the minds of the people that these liberties are of the gift of God? That they are not to be violated but with his wrath? Indeed I tremble for my country when I reflect that God is just: that his justice cannot sleep for ever. (Jefferson 174)

In a passage like this, the Puritan terror of losing God's favour is quite clear, and that is why Simpson equates Jefferson's anxious remarks to what he defines as the "apostatic imagination" (Dispossessed 14), the dreadful vision of the "absence and withdrawing of God from his vineyard" (Dispossessed 7). The white southern pastoral contains the seeds of its own destruction, a gothic undertow that threatened its existence from the very beginning.

In order to maintain the pastoral illusion, the South had to develop a "culture of alienation" (Simpson, Dispossessed 34), and it did so by estranging itself from its history and pretending that plantations were the closest possible reproduction of the garden of Eden. This kind of attitude is clear in works such as Swallow Barn by John Pendleton Kennedy and Uncle Remus: His Songs and His sayings by Joel Chandler Harris, where the antebellum South is romanticized and slavery is described as a benign, paternal attitude towards people that were happy with their condition. The process of removal and sublimation is clear in these works, and clearly expressed in their geographical dimension - a pastoral "illusion, or worse, a falsification" (Simpson, Dispossessed 58). From a strictly geo-literary point of view, the antebellum South (and the texts that openly evoke that specific here-and-now) expresses what Mikhail Bakhtin defined as the idyllic chronotope: "an-organic fastening-down, of grafting of life and its events to a place, to a familiar territory with all its nooks and crannies, its familiar mountains, valleys, field, rivers and forests, and one own's home" (225). The peculiar element in this make-believe idyll is that it barely hides the gothic destruction 
lurking in its core, the anti-pastoral landscape of social and moral decadence envisioned by Jefferson in its treatise. As long as the South could project its mind and social structures on the real-and-imagined ${ }^{2}$ space of the plantation (which is unrealand-feigned at the same time) and the rural landscape at large, the implicit darker geographies looming in the southern subconscious remained generally unexpressed. The orderly Puritan landscape, in which pastoral and gothic spaces are neatly divided, takes a different shape in the South, where in a somewhat metanarrative fashion, the pastoral space contains the gothic.

The traditional southern psycho-geographical palimpsest shattered on April 9th 1865, when General Robert E. Lee surrendered the Army of Northern Virginia at Appomattox. Its shreds were further scattered when, during and after the Reconstruction, the traditional southern milieu was more and more assimilated into modernity and capitalist modes of production. Given the fierce resistance that the Twelve Southerners expressed against this change of paradigm, it is remarkable that among the first novels which clearly expressed a post-southern sense of place, there is one that was written by a member of the group: Robert Penn Warren's All the King's Men. Warren had contributed to I'll Take My Stand with one of the most controversial pieces, "The Briar Patch", a perfect example of the faux paternal attitude of the conservative white elite towards African Americans. In this piece, the defence of a rural South vehiculates clear indications towards the prosecution of segregation: "If the southern white man feels that the agrarian life has a certain irreplaceable value in his society, and if he hopes to maintain its integrity in the face of industrialism or its dignity in the face of agricultural depression, he must find a place for the negro in his scheme” (Warren, “Patch" 263). The will to hold on to Jefferson's geo-political scheme is clear, but sixteen years later Warren's depiction of the South with All the King's Men will turn out to be totally detached from the revanchism of his youth.

The story of Willie Stark and Jack Burden (nomen omen) is also a historical chronicle of the Old South's dissolution. On the background of the political fiction plot, Jack's research as a historian of the South (and his own family's history) provides an almost orthodox gothic tale of a dynasty's demise and of the power of the past to

\footnotetext{
2 The definition derives from Edward W. Soja's Thirdspace: Journeys to Los Angeles and Other Realand-Imagined Places. In Soja's terminology, a real-and-imagined space is where "subjectivity and objectivity, the abstract and the concrete, the real and the imagined" come together (57). Although Soja's work concerns urban landscapes, literature, by means of its complex relationship with the world of actuality, is a perfect medium for this kind of all-encompassing synthesis.
} 
destroy the present. The novel is marked by a strong dynamism and a clear departure from the traditional plantation Dixie - Burden's continuous oscillation to and from his family's property in Louisiana is also a movement back and forth between the remnants of a past southern culture, geographically expressed by the pseudo aristocratic estate, and the fast changing world of contemporary southern politics and economy. "My heart was in Burden's Landing” (Warren, King's Men 187), he admits, showing his split existential condition and his estrangement from the time he so ardently tries to inhabit. In spite of its tragic development, Warren's novel is nonetheless a story of acceptance and growth with respect to the South's inability to rethink itself in the shifting landscape of contemporaneity. At the end, Jack Burden's decision to "go out of the house and go into the convulsion of the world, out of history into history and the awful responsibilities of time" (Warren, King's Men 661) demonstrates the will to break free from the pastoral entrapment's "cyclic rhythmicalness" (Bakhtin 225) and embrace the passing of time that the mind of the South (in its inability to acknowledge the fall of the Arcady with which it identified) vehemently denied.

As the attachment to the Old South waned through the years, literary approaches to the relationship between pastoral and post-pastoral (or even antipastoral, and hence, gothic) psychological geographies will take a strong turn towards the latter. An interesting depiction of post-southern space dynamics, this time from the standpoint of poor whites, is presented in Cormac McCarthy's The Orchard Keeper. The novel is structured as to gravitate around a decayed pastoral symbol: old Arthur Ownby's orchard. In spite of its clearly anti-Edenic qualities 3 this garden still functions as a "center of value, a source of moral authority" (Ragan 17). That is because notwithstanding its miserable state, the orchard still embodies the minimum requirement of a pastoral space: "the need of people in a rapidly changing world to have a vision of an understandable order" (MacKethan 6). Although the author's sympathy clearly stands with the old mountaineer and its general attitude towards contemporary times is that of an understated conservativeness, the way in which the space of the orchard is symbolically constructed is a poor substitute for a prelapsarian (or even antebellum) pastoral haven. As a matter of fact, Ownby's grove bares a symbolical resemblance to the way in which Edenic and gothic imagery mingle in the

\footnotetext{
3 In the novel, McCarthy defines Ownby's property as "the wreckage of the orchard" (Orchard 52).
} 
southern garden so that it could even be argued that in creating his setting, McCarthy was somewhat consciously or unconsciously influenced by the Jeffersonian tradition. The narration, which will bring Ownby's garden and his rural ways to their destruction, is jump-started when the corpse of a lowlife is dumped in one of the orchard's spray tanks by a bootlegger. When the old man finds it, he decides to leave it where it is, tending to it in a kind of shamanic yearly ritual but mostly avoiding to acknowledge its presence. Although the putrescent corpse has no connection whatsoever with the removed but still haunting presence of slavery as presented by Jefferson and formalized by Lewis P. Simpson, its symbolical weight in The Orchard Keeper has the same surreptitious ability to slowly erode the pastoral realm from within. As a result, the orchard keeper will be expelled from his space of "pastoral independence and pastoral permanence" (Simpson, Dispossessed 17), reproducing the biblical lapsarian dynamics of the fall of humankind.

From The Orchard Keeper to Suttree (his last southern novel before The Road), McCarthy's work reflects an increasing immersion into the gothic landscape of postsouthernness. In Outer Dark, the endless wanderings of the two protagonists (a dark parody of the traditional southern family) reflect a deep existential disorientation. The atmosphere is further exacerbated by the nightmarish qualities of the landscape, an inversion of the traditional pastoral motives into a literal "garden of the dead" (McCarthy, Dark 242).4 In Child of God, maybe his most southern gothic book to date, the expropriation of land lamented by the Twelve Southerners marks Lester Ballard's free fall into a morbid world of murder, madness and obscurity, geographically symbolized by the underground system of caves and tunnels he inhabits after his farm is put up for auction. "Were there darker provinces of the night," McCarthy writes, "he would have found them" (Child 23). Finally, Suttree, a novel of existential angst similar to All the King's Men in its depiction of the decadence of the southern aristocracy, but closer to Walker Percy's The Moviegoer in its moral and philosophical dimension, dramatizes a total rupture with the contemporary South, stemming from the homonymous protagonist's inability to live in the chaotic overlapping of post-pastoral and gothic spaces that characterizes the novel's urban landscape.

\footnotetext{
4 The setting of Outer Dark is actually multifaceted. Although gothic landscapes dominate the narration, the character of Rinthy is often surrounded and protected by a pastoral atmosphere. The novel is a good example of how gothic and pastoral landscapes mingle in post-southern literature.
} 
If one were to map the evolution of the southern landscape based on these novels, it could be possible to trace a process of disintegration and hybridization. At first, the boundaries between pastoral and gothic spaces inherited by the Puritan symbolical space and mirrored by the Jeffersonian garden/plantation are brought down - southern Arcady loses its defensive walls against the apostatic wilderness, threatening it from within. Then, since a recognizable centre of value does not hold up anymore and a coherent mapping of the characters' surroundings is not possible, the psychological and geographical setting falls into a substantial ambiguity in the way it hosts, reflects or participates in the plot. Post-southern geographies, in accordance to Bertrand Westphal's assertion about every postmodern formulation of space as inherently heterogeneous (46), exhibit a fundamental fluidity, a hybrid quality that allows them to sweep the spectrum enclosed between the opposite poles of pastoral and gothic. 5 This is exactly what happens in Cormac McCarthy's Outer Dark, in which the parallel advancement of the two protagonists' arc is alternatively tinged with dark or (pseudo-) Edenic tones when it comes to the landscape, making it a shifting, unpredictable and polysemous setting.

From a strictly theoretical point of view, the resistance that post-southern literary landscapes offer to the possibility of a stable mapping can be explained with Fredric Jameson's description of the decline of cognitive mapping in post-modernity. In Jameson's Postmodernism, or: The Cultural Logic of Late Capitalism, cognitive mapping is considered to be a product of a subject's understanding of their position within a specific cultural space and is defined as the subject's "Imaginary relationship to his or her Real conditions of existence" (51). The fact that Jameson (through Althusser) connects the dynamics of cognitive mapping to ideology is all too relevant in the southern milieu, as the Jeffersonian roots of the Dixie Edenic imagery demonstrate that far from being just a literary mode, pastoralism in the South is also informed by a strong political view. ${ }^{6}$ Although Jameson applies this theoretical tool to the analysis of the individual's actual and psychological position in the contemporary

\footnotetext{
5 Given the postulations of post-southernness that inform my analysis - Simpson's Dispossessed Garden (and especially the last chapter, "The Southern Recovery of Memory and History") and "The Closure of History in Postsouthern America", and Martyn Bone's The Postsouthern Sense of Place - I believe that postmodernity and post-southernness can be approached through a similar theoretical apparatus; hence the mention of Westphal's postmodern geographies, and later, of Jameson's studies in postmodernism.

${ }^{6}$ For a thorough analysis of the ideological dimension of the southern pastoral, see John M. Grammer, Pastoral and Politics in the Old South.
} 
urban landscape, cognitive mapping is also useful in describing how literature represents post-southern landscapes after the ordering monolith of the pastoral (represented by the traditional rural society) has been fragmented by the disintegrating powers of industrial society. If cognitive mapping "enables a situational representation on the part of the individual subject to that vaster and properly unrepresentable totality which is the ensemble of society's structures as a whole" (Jameson 51), its decline under the dispossessing action of a post-agrarian society is reflected in the instability between pastoral and gothic palimpsests that novels like McCarthy's Outer Dark, Robert Penn Warren's All the King's Men or more recently, Sara Taylor's The Shore, reveal.

The arché-space of the Old South was the garden. The post-southern landscape could perhaps be best represented by the geographical model of the wetland; or more suggestively and culturally appropriate, of the delta. This somewhat audacious metaphor derives from Gilles Deleuze and Félix Guattari's considerations on smooth and striated spaces contained in $A$ Thousand Plateaus: Capitalism and Schizophrenia. Without dwelling too much on their complex psycho-geographical model, I suggest that the mixture of nomadic (smooth, unordered) and sedentary (striated, regulated) spaces can be translated into the relationship between the gothic and the pastoral exhibited by post-southern places. If the connection of pastoral and striated spaces is self-explanatory on the basis of the order that is superimposed on them by ideological and social structures (Deleuze and Guattari define striated spaces in relation to the state apparatus), the comparison between the smooth and the gothic can be less intuitive - although A Thousand Plateaus openly suggests that the gothic (in the architectural sense) belongs to a smooth space (364). Therefore, to understand this comparison better, it is necessary to return to the exploration of the sense of place.

In The Encyclopedia of Southern Culture, Charles Reagan Wilson defines the sense of place through its connections with an organic society and through its ability to give an "abiding identity because places associated with family, community, and history have depth" (1137). The shift towards industrialism deprived the South of the grounds in which it rooted its identity, with the result that the stable, unchangeable pre-modern pastoral world was slowly eroded by an unpredictable, threatening space not defined by any sense of belonging. Since gothic spaces derive from "literary appropriations of labyrinthine enclosures" (Weston 19), the functional cognitive mapping that was reflected in the ordered space of the garden before the fall of Dixie 
is transfigured into the disorienting space of a maze, a complex setting that challenges the possibility to achieve a coherent situational representation (as Jameson writes). In accord with Deleuze and Guattari's description of smooth and striated space existing only in a mixture, a maze is an apparently highly ordered striated space that actually works in generating a cognitive chaos in the character who is trapped there because of its basic function as a structure that enhances disorientation. Moreover, if striated spaces are populated by sedentary societies (like the ones implied by Bakhtin's definition of the idyllic chronotope) and smooth spaces are inherently nomadic, a maze, by ensnaring and forcing characters to relentlessly (and often uselessly) move forward in order to find a way out, is by all means a perfect example of the spatial hybridity described in A Thousand Plateaus. Smoothness does not foster freedom in post-southernness, but rather inflicts a kind of cosmic homelessness - a perfect inversion of the traditional pastoral sense of place, inherently gothic in its narrative function. Novels like Outer Dark and William Faulkner's As I Lay Dying reflect through their strong dynamism the degradation of the southern sense of place. The impossibility for the characters to find a stable connection with the spaces they cross is a demonstration of its uncertain existential outcomes.

Therefore, the delta, with its unmappable mixture of smooth water and striated land and its continuous movements of territorialization and deteritorialization (as defined by Deleuze and Guattari), substitutes the garden in post-southern literature as the best symbolical representation of space. In so doing, contemporary southern culture comes to be characterized also by unwilling eradication, lostness, and existential uncertainty, all symbolized by the unsteady ground upon which it stands. Suspended between the fading remnants of a fallen culture and the dark harrowing depths of a deep-seated existential Unheimlich (in the etymological meaning of not homely, unfamiliar), post-southern literature inhabits a space populated by ghosts. The strong drive towards Gothicism that characterizes it should come as no surprise.

It is suggestive, then, that some recent examples of contemporary southern gothic literature are (at least partially) set in swamps, marshes and generally shifting land.7 I would like now to focus my attention on one of the most remarkable of these novels: Jesmyn Ward's Sing, Unburied, Sing. Although set in the Mississippi Delta (at least geographically, a firmer land if compared with the actual delta of the Mississippi

7 Among these, Sara Taylor's The Shore, Tiffany Quay Tyson's The Past is Never, and Delia Owen's Where the Crawdads Sing. 
River) this sophisticated novel is relevant in this context because it tackles the chaos and loss of post-southernness from the standpoint of the African-American community (the potential seed of destruction planted in the illusory southern garden by Thomas Jefferson himself). Ward's narrative is a road novel, and hence, another example of the nomadic condition of the contemporary southern psyche. It is also a representation of the chaotic relationship between space and place that belongs to the post-southern chronotope. Literal ghosts populate the novel, forcing memory on the present and disrupting it by breaking the characters' narratives and drawing them back into a traumatic past that is both personal and cultural. "This place binds you. This place blinds you" (Ward 191) says the ghost of Richie, a former young inmate of the ominous Parchman prison, showing how contemporary southern space is often a mazy entrapment rather than grounds for identity.

However, the South was surely never a pastoral space for African-Americans, chained to their places as slaves before the Civil War and representing a segregated minority after the war. In Dirt and Desire: Reconstructing Southern Women Writing, 1930-1990, Patricia Yaeger defines southern space in a decidedly gothic fashion, writing that "southern 'place' yields the remains of foundation-bearing black folks who lie beneath the earth" (20). Read in this light, Richie's affirmation that "Home is about the earth. Whether the earth open up to you. Whether it pull you so close the space between you and it melt and y'all one" (Ward 182-183) gains a disturbing undertone, qualifying southern ground, first and foremost, as a graveyard. While in The Orchard Keeper (a thoroughly white novel) a decayed but still functional garden is the moral centre of the story, in Ward's novel, the pivot of the narration is Parchman prison. This prison, a notorious hell on earth, clearly refigures in its connotation the actual living conditions of a plantation completely stripped of the traditional pastoral romanticization: "From sunup to sundown we was out there in them [cotton] fields, hoeing and picking and planting and pulling. (...) Men strung out across the fields, the trusty shooters stalking the edge, the driver on his mule, the caller yelling to the sun, throwing his working song out" (Ward 68-69). The moral centre becomes a traumatic centre, the resonance of an older space of horror that is the negation (or better, the actual representation) of the almost sacred southern pastoral space.

The idyllic southern chronotope denied the passing of time and the "dispossessing powers of modern history" (Simpson, Dispossessed 64) in order to reaffirm itself in the face of modernity, but this attitude is reversed in the anti-pastoral 
(or gothic) chronotope of a novel like Sing, Unburied, Sing, where the possibility to live in an eternal cycle is denied by the intrusion of traumatic memories vehiculated by ghosts. The southern gothic is already a negation of the serene "rhythmicalness" that Bakhtin associates with pastoral chronotopes (one needs not to quote again Faulkner's statement from Requiem for a Nun to prove it), but in Ward's novel, just like in its closest antecedent, Toni Morrison's Beloved, the past literally and concretely comes back to crack the wholeness of the present. Since space and time are intrinsically connected in literary geographies, it is worth analysing these chronological disjunctions in order to better understand southern space as presented in contemporary African-American gothic literature written by women - or, at least, in the way Ward and Morrison approach southern space.

The presence of actual ghosts as harbingers of the past in place of the more nuanced way in which history haunts the southern gothic present in the novels of Faulkner, McCarthy, or Warren, can be explained through women writers' attitude towards the supernatural in the gothic. Hoveler states that female authors, unlike their male counterparts, do not usually draw a sharp line between the world of affairs and the hereafter, considering the two spheres as continuous, able to communicate, to be accepted, connected with, reclaimed (100). In other words, these chronotopes acknowledge space, time, history, and metaphysics all at the same time, except that the ethereal sphere is actually rooted or merged with the very concrete traumatic history of the African-American population. Unearthing the buried past of the South, Beloved and Sing, Unburied, Sing perform a political act against the erasure of reality that occurs in white pastoralism: these novels are archaeological explorations of a world "encumbered with endless melancholy" (Yaeger 19). They give voice and body to the "breath of the disremembered and unaccounted for" (Morrison 324), digging up the luxuriant southern ground to bring to light a "repellant landscape (hidden, but not completely; deliberately buried, but not forgotten)" (Morrison xi).

The focus on the ghostly layers that move under southern landscapes in contemporary African-American fiction (or, generically, the fiction that does not disremember, and accounts for) calls for a spatial analysis that also considers the action of the ghosts of southern history on its terrain. Since space has a speculative and existential dimension, while place, given its connections with family, community, and history, more properly belongs to the ontological, these spectral geographies can be defined as existing in the field of hauntology: the ontological inquiry into the nature 
of the ghosts of history that reappear in the present to claim recognition and affirmation. ${ }^{8}$ In order to regain a coherent spatial/historical mapping, "it is necessary to speak of the ghost, indeed to the ghost and with it," because "no justice (...) seems possible or thinkable without the principle of some responsibility, beyond all living present, within that which disjoins the living present, before the ghosts of those who are (...) victims of wars, political or other kinds of violence, nationalist, racist, colonialist, sexist" (Derrida xvii).

In conclusion, accepting a chronotope that presents a time out of joint seems to be, paradoxically, the only way to regain the wholeness of the sense of place for writers ethically and politically committed to a restoration of space and memory (or of memory in space). The dominant, white image of the southern literary pastoral expressed what Derrida called ontopology: "an axiomatics linking indissociably the ontological value of present-being (...) to the stable and presentable determination of a locality" (Derrida 103). Canonical novels like Beloved and more recent works like Sing, Unburied, Sing, along with C.E. Morgan's The Sport of Kings and Natasha Trethewey's Native Guard (just to name a couple of titles), seem rather to express a hauntopology, an investigation of eerie places that are "inhabited by highly vocal ghosts" (Morrison xi), haunted by a past (and a present) that fights against its silencing, its erasure at the hands of the dispossessing powers of oppression. These silences, the voids carved into the discursive patterns of southern space, are precisely where a geocritical investigation of the contemporary South should look in order to conjure the spectres lying behind the threshold of actuality and restore southern landscapes in all their dark and fascinating complexities. Space and myth have given southern literature a most enduring palimpsest. But, since a palimpsest is but a composite superimposition of layers, other traces have been covered and cancelled for it to exist in its current form. The spectral landscapes projected by these vanishing traces are to be taken back into the picture, and that is precisely what literary hauntopology should be called upon to do. With the help of a methodological approach that is part cultural geography and part séance, the deeper maps drawn by southern literature can be evoked back, and contribute a comprehensive understanding of the manifold, subtle connections between the South and its landscapes.

\footnotetext{
${ }^{8}$ My use and understanding of the term mainly derives from Jacques Derrida's Specters of Marx.
} 


\section{References:}

Bakhtin, Mikhail M. The Dialogic Imagination, edited by Michael Holquist, translated by Caryl Emerson and Michael Holquist. University of Texas Press, 1981.

Bone, Martyn. The Postsouthern Sense of Place in Contemporary Fiction. Louisiana State UP, 2005.

Cash, W.J. The Mind of the South. Vintage, 1991.

Cornelius, Steven H. Music of the Civil War Era. Greenwood Press, 2004.

Deleuze, Gilles, and Félix Guattari. A Thousand Plateaus: Capitalism and Schizophrenia. Translated by Brian Massumi, University of Minnesota Press, 1987.

Derrida, Jacques. Specters of Marx: The State of Debt, the Work of Mourning and the New International. Translated by Peggy Kamuf, Routledge Classics, 2006.

Hoeveler, Diane Long. “American Female Gothic.” The Cambridge Companion to American Gothic, edited by Jeffrey Andrew Weinstock. Cambridge UP, 2017: 99-114.

Jameson, Fredric. Postmodernism, or: The Cultural Logic of Late Capitalism. Duke UP, 1991.

Jefferson, Thomas. Notes on the State of Virginia. J.W. Randolph, 1853.

Kreyling, Michael. Inventing Southern Literature. UP of Mississippi, 1998.

MacKethan, Lucinda Hardwick. The Dream of Arcady: Place and Time in Southern Literature. Louisiana State UP, 1980.

Mather, Cotton. Wonders of the Invisible World. Observations as Well Historical as Theological, Upon the Nature, the Number, and the Operations of the Devils, edited and with an introduction by Reiner Smolinski, Digital Commons@University of Nebraska - L Lincoln, 1998, digitalcommons.unl.edu/cgi/viewcontent.cgi?article=1019\&context=etas, accessed 21 March 2020.

McCarthy, Cormac. The Orchard Keeper. 1965. Vintage, 1993.

--. Outer Dark. 1968. Vintage, 1993.

--. Child of God. 1973. Vintage, 1993.

Morrison, Toni. Beloved. 1987. Vintage, 2016. 
Ragan, David Paul. "Values and Structure in The Orchard Keeper." Perspectives on Cormac McCarthy, edited by Edwin T. Arnold and Dianne C. Luce. UP of Mississippi, 1999: 17-28.

Ransom, John Crowe. "Reconstructed but Unregenerate." Twelve Southerners, I'll Take My Stand: The South and the Agrarian Tradition. Louisiana State UP, 2006: 1-27.

Simpson, Lewis P. The Dispossessed Garden: Pastoral and History in Southern Literature. University of Georgia Press, 1975.

---. Introduction. 3x3: Masterworks of the Southern Gothic, by Doris Betts, et. al. Peachtree Publishers, 1985: vii-xiv.

Soja, Edward W. Thirdspace: Journeys to Los Angeles and Other Real-and-Imagined Places. Blackwell, 1996.

Tuan, Yi-Fu. Landscapes of Fear. University of Minnesota Press, 1980.

Twelve Southerners. I'll Take My Stand: The South and the Agrarian Tradition. Louisiana State UP, 2006.

Ward, Jesmyn. Sing, Unburied, Sing. Scribner, 2017.

Warren, Robert Penn. "The Briar Patch.” Twelve Southerners, I'll Take My Stand: The South and the Agrarian Tradition. Louisiana State UP, 2006: 246-264.

--. All the King's Men. Penguin, 2007.

Weston, Ruth D. Gothic Traditions and Narrative Techniques in the Fiction of Eudora Welty. Louisiana State UP, 1994.

Wesphal, Bertrand. Geocriticism: Real and Fictional Spaces. Palgrave Macmillan, 2011.

Wilson, Charles Reagan. "Place, sense of." The Encyclopedia of Southern Culture, edited by William Ferris and Charles Reagan Wilson, University of South Carolina Press, 1989.

Yaeger, Patricia. Dirt and Desire: Reconstructing Southern Women Writing. The University of Chicago Press, 2000. 